\title{
The Evaluation of Teachers' Job Performance Based on Total Quality Management (TQM)
}

\author{
Nayereh Shahmohammadi ${ }^{1}$ \\ ${ }^{1}$ Organization for Educational Research and Training, Ministry of Education, Tehran, Iran \\ Correspondence: Nayereh Shahmohammadi, Organization for Educational Research and Training, Ministry of \\ Education, Tehran, Iran. E-mail: nsh_teh@yahoo.com
}

Received: October 20, 2016

Accepted: November 27, $2016 \quad$ Online Published: March 30, 2017

doi:10.5539/ies.v10n4p58

URL: https://doi.org/10.5539/ies.v10n4p58

\begin{abstract}
This study aimed to evaluate teachers' job performance based on total quality management (TQM) model. This was a descriptive survey study. The target population consisted of all primary school teachers in Karaj ( $\mathrm{N}=2917)$. Using Cochran formula and simple random sampling, 340 participants were selected as sample. A total quality management model-based researcher made questionnaire was used for collecting the data. Its validity was confirmed by experts. The pilot study was conducted on 30 participants; using Cronbach Alpha formula, its reliability was determined to be 0.813 . The data were analyzed using SPSS software in two descriptive (median, mean, mode, standard deviation, skewness) and inferential (one-sample $T$ test) levels. The findings showed that at $\alpha=0.05$ level, the teachers' job performance was higher than mean. At $\alpha=0.05$ level, also, the teachers' job performance in process design, management, process improvement, public participation, and focus on customer was higher than mean.
\end{abstract}

Keywords: performance evaluation, total quality management, process design, management, process improvement, public participation, focus on customer

\section{Introduction}

The job performance is the most critical issue in any organization. The importance of job performance has prompted researchers to study more about it (Shokrkon et al., 2001). From a social perspective, organizations are looking for employees who can perform well in their jobs and have a good performance. The good performance increases organizational productivity and is associated with promotion in national economy (Writ, 2004). The job performance is one of the issues has attracted attentions in many developed countries. The psychologists consider job performance as a product of human behavior. They believe that motivations and needs impact on performance of individuals and ultimately it has effect on economic growth and development (Ferres \& Fie, 2001). Also, it is believed that job performance is a mixed structure. Based on this structure and using a set of specific criteria, the successful employees may be distinguished from unsuccessful employees (Austin \& Villaova, 1992). In addition, the performance is defined as expected values of organization which are conducted by individuals during a given period of time (Motowidlo, 2003).

Considering the importance of human resources in an organization, the teachers are the most important factor in education systems. They take the first step in training of human resources and are responsible for training of future human society (Salimi, 2015). Similarly the education systems play a major role as the most significant investment on human resources in the field of prosperity of society. Considering their importance and their role in economic, social, cultural, and political dimensions in community, it is necessary that basic measures are taken to improve the quality of education systems and prevent from human capital and material loss. Accordingly the management is very important in these systems.

There are various evaluation models one of which is Total Quality Management (TQM). TQM is an approach that may cause evolution in education system lead to increase in productivity and efficiency. Sallies believes that total quality management is continuous improvement philosophy which is able to provide a set of practical tools and techniques to meet the current and future needs, wants, and expectations of any education institution. Since the organizations and education centers are the main centers for providing human resources and determining factors for preparing them for manufacturing and service organizations in community, it is necessary more than ever to study and implements the quality management principles in education. The quality in education and 
schools is the changes in student behavior in all aspects; i.e., it has comprehensiveness and universality (Turan, 2003).

Many studies were conducted on total quality management and showed its importance and impacts on an organization improvement. In Iran, Safari et al. (2012) investigated the structure of quality management with information technology support in Central Insurance of Iran. The findings showed that quality management aspects in organizations are generally influenced by information technology. The performance of organizations is largely dependent on information. Also, the information technology had the greatest impact on customer satisfaction. Also, Valimohammadi (2010) investigated the philosophy of total quality management. The total quality management is an approach to improve the competitiveness, effectiveness, and flexibility of an organization. It is essentially a way to plan, organize, and understand activities and relies on individuals in each level of organization. The total quality management is also a way to screen individuals' activities and guide them toward improvement processes; the result will be achievement in a shorter time.

Another research by Hamidizadeh and Babadi (2010) studied the Impact of total quality management implementation on business processes improvement in Economic and Finance Affairs Department in Khuzestan. This study tried to provide a new insight on dependence of total quality management components on business processes improvement methodology component. Using statistical models, also, it studied the impact of total quality management system on business processes improvement. Similar to this study, Neiestani et al. (2010) investigated the impact of TQM on organizational performance in research and development environment in manufacturing companies in Markazi province. They found that TQM has an effect on organizational performance.

In other countries, Manian et al. (2009) studied the relationship between information technology and business alignment and organizational performance in information technology companies. The findings showed that the alignment of IT and business is a key to achieve improved performance, especially in internal processes. Also, Spin et al. (2013) conducted a study on Spanish companies. It was found that the adhocracy culture had a positive impact and the hierarchical and market cultures had a negative impact on total quality management; the tribal (group) culture had no significant effect.

The other study NIST (2011) found that evaluation model and criteria of award are reviewed and revised almost every year. The award edition model in 2011 is made up of seven main criteria: leadership/strategic planning/focus on customer/measurement, analysis, and knowledge management/focus on human resource/focus on operations/results. In results section, the organizational performance and improvement in all main areas are assessed. These areas include the product and process achievements/customer-oriented achievements/human resources-focus achievements/leadership and governance achievements, and financial and market achievements.

Wai, Seebaluck, and Teeroovengadum (2011) examined the impact of information technology on quality management dimensions. They found that information technology has an impact on quality management. Also, Moisture (2004) found that the total quality management is a system which includes quality and customer satisfaction. It covers the techniques and methods of management and quality in a comprehensive and integrated manner. In general, the companies which implement the total quality management philosophy should be sure about continuous quality improvement efforts in all parts of organization. The move towards continuous improvement process often begins by adopting a philosophy of quality management such as principles of Deming, Juran philosophy, or Crosby philosophy.

All above studies focused on non-educational organizations and no research has been done on total quality management on schools and teachers 'performance. Thus this study aims to evaluate the performance of teachers using TQM model and tries to answer following questions:

- How is the teachers' job performance in terms of process design?

- How is the teachers' job performance in terms of management?

- How is the teachers' job performance in terms of process improvement?

- How is the teachers' job performance in terms of public participation?

- How is the teachers' job performance in terms of focus on customer?

This study also performs the pathology of their performance, identify strengths, weaknesses, and obstacles in their performance, and provide solutions for quality improvement of teachers' performance.

\section{Methodology}

The objectives of this study was Evaluating teachers` job performance in terms of Total Quality Management. 
This was an applied-descriptive survey study. The population consisted of all primary school teachers in Karaj $(\mathrm{N}=2917)$. Using Cochran formula and simple random sampling, 340 participants were selected as sample. A total quality management model-based researcher made questionnaire was used for collecting the data. It consisted of 50 questions in five dimensions: process design (questions 1 to 10), management (questions 11 to 20), process improvement (questions 21 to 30), public participation (questions 31 to 40) and focus on customer (questions 41 to 50). The validity of tool was confirmed by experts. The pilot study was conducted on 30 participants; using Cronbach Alpha formula, its reliability was determined to be 0.813 .

Table 1. Reliability of questionnaire's component based on TQM

\begin{tabular}{cc}
\hline Components & Reliability \\
\hline process design & $\mathbf{0 . 7 4}$ \\
management & $\mathbf{0 . 6 5}$ \\
process improvement & $\mathbf{0 . 6 7}$ \\
public participation & $\mathbf{0 . 9 6}$ \\
focus on customer & $\mathbf{0 . 8 5}$ \\
\hline
\end{tabular}

The data were analyzed using SPSS software in two descriptive (median, mean, mode, standard deviation, skewness) and inferential (one-sample T test) levels

\section{Findings}

According to the findings of descriptive statistics, $93 \%$ of participants were women and 7 percent were men. Considering age group, 3 percent of respondents were belong to the age group 20 to 25 years, 10 percent to the age group 25 to 30,38 percent to the age group 30 to 35,23 percent to age group 35 to 40,12 percent to age group 40 to 50 and 14 percent to age group 50 and above. Distribution of qualification among respondents included: 8 percent of respondents had high school degree, 82 percent had a bachelor's degree and 10 percent master degree. Among respondent, 45 percent had 5 to 10 years of experience, 17 percent had 10 to 20 years of experiences, 14 percent had above 20 years of experiences and 14 percent had below 5 years of experiences. The average index for all components of total quality management( process design, management, process improvement, public participation and focus on customer ) were all above 3, except for focus on customer was below 3 .The findings of investigating research questions were as follows:

First question: How is the teachers' job performance in terms of process design?

Table 2. T-test on the teachers' job performance in terms of process design

\begin{tabular}{|c|c|c|c|c|c|c|c|c|c|c|c|}
\hline $\begin{array}{c}\text { Mean } \\
\text { standard } \\
\text { error }\end{array}$ & SD & Mean & $\mathbf{N}$ & $\begin{array}{c}\text { Mean difference } \\
\text { of scores }\end{array}$ & \multicolumn{2}{|c|}{$\begin{array}{c}\text { Confidence level } \\
(95 \%)\end{array}$} & t-value & df & $\begin{array}{l}\text { Sig. level } \\
\text { ( } 2 \text { tailed) }\end{array}$ & $\begin{array}{l}\text { t table } \\
(0.05)\end{array}$ & $\begin{array}{c}\mathrm{t} \\
\text { table } \\
(0.01) \\
\end{array}$ \\
\hline \multirow[t]{2}{*}{0.03119} & \multirow[t]{2}{*}{0.57513} & \multirow[t]{2}{*}{3.67} & \multirow[t]{2}{*}{340} & \multirow[t]{2}{*}{0.67} & $\begin{array}{l}\text { High } \\
\text { level }\end{array}$ & $\begin{array}{c}\text { Bottom } \\
\text { level }\end{array}$ & \multirow[t]{2}{*}{21.481} & \multirow[t]{2}{*}{339} & \multirow[t]{2}{*}{0.000} & \multirow[t]{2}{*}{1.9} & \multirow[t]{2}{*}{2.3} \\
\hline & & & & & 0.7314 & 0.6086 & & & & & \\
\hline
\end{tabular}

According to Table 2, the calculated $\mathrm{t}(\mathrm{t}=21.481)$ was greater than the $\mathrm{t}$ in the table in 339 degrees of freedom and in error level of 0.05 and 0.01 ; the significance level of test was zero (less than 0.05). Also, the top and bottom levels in 95 percent confidence level were positive for this variable; this showed that the mean of this variable was more than 3 . With $99 \%$ confidence, therefore, it can be concluded that teachers' job performance in this area was above expected mean (between 3 and 4).

Second question: How is the teachers' job performance in terms of management? 
Table 3. T-test on the teachers' job performance in terms of management

\begin{tabular}{|c|c|c|c|c|c|c|c|c|c|c|c|}
\hline $\begin{array}{c}\text { Mean } \\
\text { standard } \\
\text { error }\end{array}$ & SD & Mean & $\mathbf{N}$ & $\begin{array}{c}\text { Mean } \\
\text { difference } \\
\text { of scores }\end{array}$ & Confid & $\begin{array}{l}\text { ce level } \\
\text { o) }\end{array}$ & t-value & df & $\begin{array}{l}\text { Sig. level } \\
\text { (2tailed) }\end{array}$ & $\begin{array}{c}\text { t table } \\
(0.05)\end{array}$ & $\begin{array}{c}t \text { table } \\
(0.01)\end{array}$ \\
\hline \multirow[t]{2}{*}{0.02589} & \multirow[t]{2}{*}{0.47747} & \multirow[t]{2}{*}{3.5915} & \multirow[t]{2}{*}{340} & \multirow[t]{2}{*}{0.59147} & $\begin{array}{l}\text { High } \\
\text { level }\end{array}$ & $\begin{array}{c}\text { Bottom } \\
\text { level }\end{array}$ & \multirow[t]{2}{*}{22.841} & \multirow[t]{2}{*}{339} & \multirow[t]{2}{*}{0.000} & \multirow[t]{2}{*}{1.9} & \multirow[t]{2}{*}{2.3} \\
\hline & & & & & 0.6434 & 0.5405 & & & & & \\
\hline
\end{tabular}

According to Table 3, the calculated $t(t=22.841)$ was greater than the $t$ in the table in 339 degrees of freedom and in error level of 0.05 and 0.01 ; the significance level of test was zero (less than 0.05). Also, the top and bottom levels in 95 percent confidence level were positive for this variable; this showed that the mean of this variable was more than 3 . With $99 \%$ confidence, therefore, it can be concluded that teachers' job performance in this area was above expected mean (between 3 and 4).

Third question: How is the teachers' job performance in terms of process improvement?

Table 4. T-test on the teachers' job performance in terms of process improvement

\begin{tabular}{|c|c|c|c|c|c|c|c|c|c|c|c|}
\hline $\begin{array}{c}\text { Mean } \\
\text { standard } \\
\text { error } \\
\end{array}$ & SD & Mean & $\mathbf{N}$ & $\begin{array}{c}\text { Mean } \\
\text { difference of } \\
\text { scores } \\
\end{array}$ & \multicolumn{2}{|c|}{$\begin{array}{c}\text { Confidence level } \\
(95 \%)\end{array}$} & t-value & df & $\begin{array}{l}\text { Sig. level } \\
\text { ( } 2 \text { tailed) }\end{array}$ & $\begin{array}{l}t \text { table } \\
(0.05)\end{array}$ & $\begin{array}{l}\mathrm{t} \text { table } \\
(0.01)\end{array}$ \\
\hline \multirow[t]{2}{*}{0.2806} & \multirow[t]{2}{*}{0.51746} & \multirow[t]{2}{*}{3.7074} & \multirow[t]{2}{*}{340} & \multirow[t]{2}{*}{0.70735} & $\begin{array}{l}\text { High } \\
\text { level }\end{array}$ & $\begin{array}{c}\text { Bottom } \\
\text { level }\end{array}$ & \multirow[t]{2}{*}{25.206} & \multirow[t]{2}{*}{339} & \multirow[t]{2}{*}{0.000} & \multirow[t]{2}{*}{1.9} & \multirow[t]{2}{*}{2.3} \\
\hline & & & & & 0.7626 & 0.6522 & & & & & \\
\hline
\end{tabular}

According to Table 4 , the calculated $t(t=25.206)$ was greater than the $t$ in the table in 339 degrees of freedom and in error level of 0.05 and 0.01 ; the significance level of test was zero (less than 0.05). Also, the top and bottom levels in 95 percent confidence level were positive for this variable; this showed that the mean of this variable was more than 3 . With $99 \%$ confidence, therefore, it can be concluded that teachers' job performance in this area was above expected mean (between 3 and 4).

Forth question: How is the teachers' job performance in terms of public participation?

Table 5. T-test on the teachers' job performance in terms of public participation

\begin{tabular}{|c|c|c|c|c|c|c|c|c|c|c|c|}
\hline $\begin{array}{c}\text { Mean } \\
\text { standard } \\
\text { error }\end{array}$ & SD & Mean & $\mathbf{N}$ & $\begin{array}{c}\text { Mean } \\
\text { difference of } \\
\text { scores } \\
\end{array}$ & Confi & $\begin{array}{l}\text { ce level } \\
\text { o) }\end{array}$ & t-value & df & $\begin{array}{l}\text { Sig. level } \\
\text { (2 tailed) }\end{array}$ & $\begin{array}{l}t \text { table } \\
(0.05)\end{array}$ & $\begin{array}{c}\text { t table } \\
(0.01)\end{array}$ \\
\hline \multirow[t]{2}{*}{0.02447} & \multirow[t]{2}{*}{0.45116} & \multirow[t]{2}{*}{3.4209} & \multirow[t]{2}{*}{340} & \multirow[t]{2}{*}{0.42088} & $\begin{array}{l}\text { High } \\
\text { level }\end{array}$ & $\begin{array}{c}\text { Bottom } \\
\text { level }\end{array}$ & \multirow[t]{2}{*}{17.202} & \multirow[t]{2}{*}{339} & \multirow[t]{2}{*}{0.000} & \multirow[t]{2}{*}{1.9} & \multirow[t]{2}{*}{2.3} \\
\hline & & & & & 0.4690 & 0.3728 & & & & & \\
\hline
\end{tabular}

According to Table 5 , the calculated $\mathrm{t}(\mathrm{t}=17.202)$ was greater than the $\mathrm{t}$ in the table in 339 degrees of freedom and in error level of 0.05 and 0.01 ; the significance level of test was zero (less than 0.05). Also, the top and bottom levels in 95 percent confidence level were positive for this variable; this showed that the mean of this variable was more than 3 . With $99 \%$ confidence, therefore, it can be concluded that teachers' job performance in this area was above expected mean (between 3 and 4).

Fifth question: How is the teachers' job performance in terms of focus on customer? 
Table 6. T-test on teachers' job performance in terms of focus on customer

\begin{tabular}{|c|c|c|c|c|c|c|c|c|c|c|c|}
\hline $\begin{array}{c}\text { Mean } \\
\text { standard } \\
\text { error }\end{array}$ & SD & Mean & Number & $\begin{array}{c}\text { Mean } \\
\text { difference } \\
\text { of scores } \\
\end{array}$ & $\begin{array}{r}\text { Confider } \\
(95\end{array}$ & $\begin{array}{l}\text { ce level } \\
\text { \%) }\end{array}$ & t-value & Degree of freedom & $\begin{array}{l}\text { Sig. level } \\
\text { ( } 2 \text { tailed) }\end{array}$ & $\begin{array}{c}\mathrm{t} \\
\text { table } \\
(0.05) \\
\end{array}$ & $\begin{array}{c}\mathrm{t} \\
\text { table } \\
(\mathbf{0 . 0 1}) \\
\end{array}$ \\
\hline \multirow[t]{2}{*}{0.042} & \multirow[t]{2}{*}{0.78} & \multirow[t]{2}{*}{2.76} & \multirow[t]{2}{*}{340} & \multirow[t]{2}{*}{0.23029} & $\begin{array}{l}\text { High } \\
\text { level }\end{array}$ & $\begin{array}{c}\text { Bottom } \\
\text { level }\end{array}$ & \multirow[t]{2}{*}{-5.378} & \multirow[t]{2}{*}{339} & \multirow[t]{2}{*}{0.000} & \multirow[t]{2}{*}{1.9} & \multirow[t]{2}{*}{2.3} \\
\hline & & & & & $-0 / 3145$ & -0.1461 & & & & & \\
\hline
\end{tabular}

According to Table 6 , the calculated $t(t=-5.378)$ was less than the $t$ in the table in 339 degrees of freedom and in error level of 0.05 and 0.01 ; the significance level of test was zero (less than 0.05). Also, the top and bottom levels in 95 percent confidence level were negative for this variable; this showed that the mean of this variable was less than 3. With $99 \%$ confidence, therefore, it can be concluded that teachers' job performance in this area was less than expected mean (between 2 and 3).

\section{Discussion and Conclusion}

This study investigated primary school teachers' job performance based on total quality management model in Karaj province. The findings showed that the job performance of teachers based on total quality management components (process design, management, process improvement, public participation, and focus on customer) was more than expected mean (3). The highest mean was for process improvement and the least mean was for customer satisfaction. Therefore, the investment on creating process improvement system will increase efficiency in teachers' job performance. According to findings, it can be said that process improvement is emphasis on methods which evolve job performance to increase teachers' efficiency and consequently, improve the quality of education. Therefore, there is a strong need to improve teachers' job process quality and education system improvement. Undoubtedly, the quality is a factor affecting the development of industry, commerce, and education; it is one of the most important factors in organizational competitiveness and success in global markets. Therefore, the use of total quality management according to education system goals increases the effectiveness of human and material resources in organizations.

The findings of this study are consistent with research results of Safari and colleagues (2012), NIST (2011), and Moisture (2004). In their study, Safari et al. (2012) found that quality management aspects in organizations are generally influenced by information technology. The performance of organizations is largely dependent on information. Also, the information technology had the greatest impact on customer satisfaction. NIST (2011) found that organizational performance and improvement are evaluated almost in all main areas. These areas include the product and process achievements/customer-oriented achievements/human resources-focus achievements/leadership and governance achievements, and financial and market achievements. Moisture (2004) found that the move towards continuous improvement process often begins by adopting a philosophy of quality management such as principles of Deming, Juran philosophy, or Crosby philosophy.

The total quality model is a method for managing the organization. It is based on the quality and participation of all stakeholders. It aims to achieve long-term success through customer satisfaction and providing benefits of all stakeholders. The organizations are successful in competition which act based on customer needs and maximum quality. The total quality management has a systemic look on organization. It considers the schools as open social systems which will have the best performance with cybernetic method. The education systems plays a major role as the most significant investment on human resources in the field of prosperity of society. Considering their importance and their role in economic, social, cultural, and political dimensions in community, it is necessary that basic measures are taken to improve the quality of education systems and prevent from human capital and material loss. However, the total quality management was initially designed and regulated for industrial purposes, today it is entered to education and training system and is a model for quality education and factors affecting on it.

The total quality model has various components. One of its emphasized components is focus on process rather than focus purely on outcome. The continuous improvement of job process and performance will automatically improve the outcome. The pure focus on outcome should be avoided, because short-term results will lead to dissolution of system in long term.

Based on the finding showed that the job performance of teachers based on total quality management components (process design, management, process improvement, public participation, and focus on customer) was more than expected mean (3), the continuous increase of teachers and administrators' awareness (employees' 
empowerment) will not be effective as long as they are not professional, capable, and expert in their works; the teaching-learning process will remain ineffective. Thus determining the vision and mission of school for staff will prompt them to continuously adapt themselves with organization's mission, avoid from marginal tasks, act on main objectives of organization, and try for realization of goals. Also, the employee involvement in all organizational activities, particularly determining process-based strategies, should be considered by managers. It should be noted that the total quality management will be meaningless without participation of school personnel. The most important effect of employee participation is execution guarantee, because employees involve in decision makings and consider the decisions as their property (Sallies, 2002).

\section{Acknowledgments}

I thank of all the principals and teachers of Karaj province who helped in conducting this research. I am also appreciative of Karaj education department for facilitating implementation of this study.

\section{References}

Corredor, P., \& Goñi, S. (2011). TQM and performance: Is the relationship so obvious? Journal of Business Research, 64(8), 830-838. https://doi.org/10.1016/j.jbusres.2010.10.002

Haffar, M., Al-Karaghouli, W., \& Ghoneim, A. (2013). The mediating effect of individual readiness for change in the relationship between organisational culture and TQM implementation. Total Quality Management \& Business Excellence, 24(5-6), 693-706. https://doi.org/10.1080/14783363.2013.791112

Hamidizadeh, M. R., \& Babadi, S (2010). The impact of implementing total quality management on business processes improvement: Economic Affairs and Finance of Khuzestan (A case study). University-industry magazine, 9 and 10 Issues, autumn and winter.

Keller, P. (2008). TQM deployment. QA Publishing.

Kulkarni, S. (2005). Component of successful total quality management. The TQM magazine, 17(2).

Lameei, A. (2003). Total quality management; principles, application and lessons from an experience. Oroumiyeh: Moaseseie Farhangi Entesharatie Shahed va Isargaran.

Manian, A., Mousa-Khani, M., \& Parzami, M. (2009) .The relationship between information technology and business alignment and organizational performance in companies operating in information technology: using structural equation modeling. Journal of Information Technology Management, 1(3), 89-106.

Matha, K. M. (2004). Examination the relationships between motivational traits and counterproductive work behaviors. The Department of Psychology (A Thesis Submitted to the Graduate Faculty of the Louisiana State University and Agricultural and Mechanical College in partial fulfillment of the requirements for the degree of Master of Arts, Emory University).

Motowidlo, S. J. (2003). Job performance. Handbook of psychology (pp. 39-53). https://doi.org/10.1002/0471264385.wei1203

Neiestani, A., Farsijani, H., \& Bolhasani, A. (2010). The effects of TQM on organizational performance in research and development enviornment. Journal of Industrial Management, Islamic Azad University, Sanandaj Branch, 5(14), 75-88.

NIST. (2011). Criteria for Performance Excellence. American Society for Quality (ASQ), USA.

Rotundo, M., \& Sackett, P. R. (2002). The relative importance of task, citizenship, and counterproductive performance to global ratings of job performance: A policy-capturing approach. Journal of applied psychology, 87(1), 66. https://doi.org/10.1037/0021-9010.87.1.66

Safari, S., Shirzad, S., \& Khalil, H. (2012). Quality management structure with information technology support (Central Insurance of Iran: A case study). Journal of Information Technology Management, 4(12), 113-134.

Sallis, E. (2014). Total quality management in education (p. 107). Routledge.

Shokrkon, H., Nisei, A., Naami, A., \& Mehrabizadeh, H. M. (2001). Relationship between job satisfaction and job performance and civil behavior of employees in some factories in Ahvaz. Journal of Education and Psychology, Shahid Chamran University (Psychology). 3\&4(8), 24-33.

Stamatis, D. H. (1996). Total quality management in healthcare: Implementation strategies for optimum results. Irwin Professional Publishing.

Tavalaee, R. (2012). New approaches to assessing organizational performance. Database of management scientific articles. 
Valimohammadi, C. (2010). Quality management and productivity (2nd ed.). Tehran: Islamic Azad University, South Tehran Branch.

Vischer, J. C. (2007). The effects of the physical environment on job performance: towards a theoretical model of workspace stress. Stress and Health, 23, 175-184. https://doi.org/10.1002/smi.1134

Wai, S. M. D. L., Seebaluck, A. K., \& Teeroovengadum, V. (2011). Impact of information technology on quality management dimensions and its implications. European Business Review, 23(6), 592-608. https://doi.org/10.1108/09555341111175426

\section{Copyrights}

Copyright for this article is retained by the author(s), with first publication rights granted to the journal.

This is an open-access article distributed under the terms and conditions of the Creative Commons Attribution license (http://creativecommons.org/licenses/by/4.0/). 